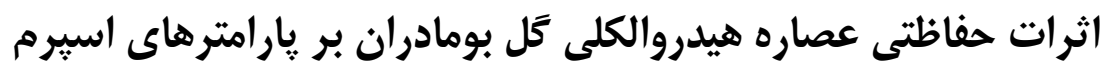

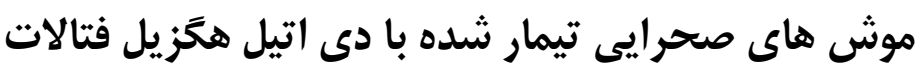

$$
\text { زهرا كريم يور على آباد'، شايور حسن زاده"، مزدى رازى }
$$

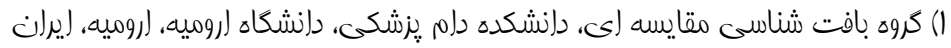

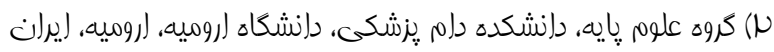

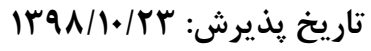

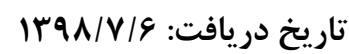

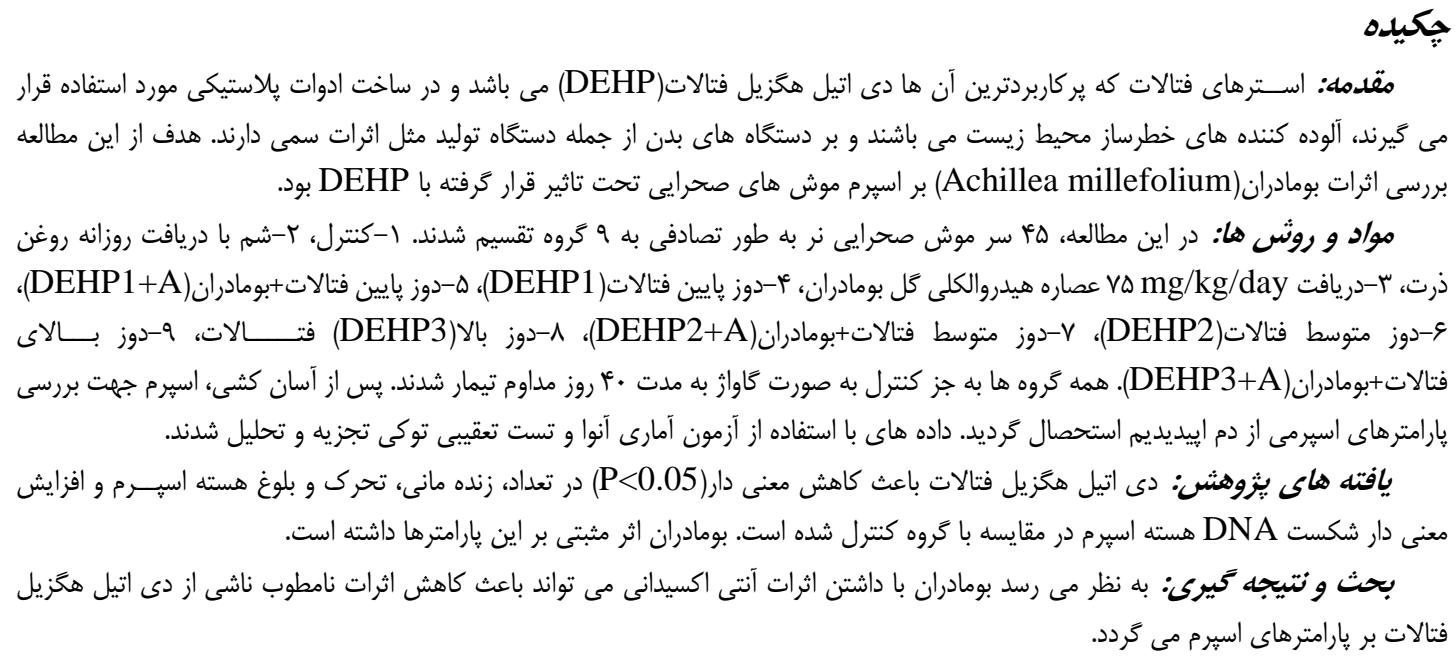

\section{Email:}

* نويسنده مسئول: گروه علوم پايه، دانشكده دام يزشكى، دانشخاه اروميه، اروميه، ايران

Copyright ( 2019 Journal of Ilam University of Medical Science. This is an open-access article distributed under the terms of the Creative Commons Attribution international 4.0 International License (https://creativecommons.org/licenses/by-nc/4.0/) which permits copy and redistribute the material, in any medium or format, provided the original work is properly cited. 
موجب ايجاد ســـرطان بيضه، سرطان سينه، كاهش

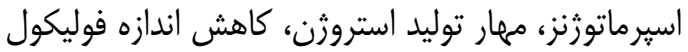

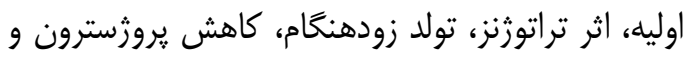
Lايا، افزايش FSH

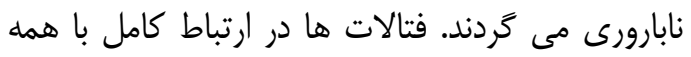
افراد اجتماع مى باشند و انسان ها خواسته و ناخواسته از طريق تماس خوراكى، يوستى و استنشاقى در مواجه با بانسا

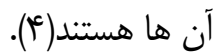
استرهاى فتالات كه به طور گسترده در وسايل يلاستيكى و بسته بندى هاى غذايى استفاده مى شوند. جز آلوده كنتده هاى خطرناى بندئ محيط هاى بيولوزيكي

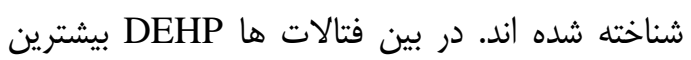

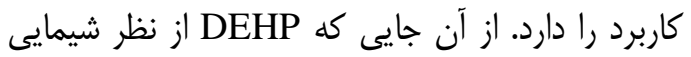
به يليمر متصل نمى شود در زمان توليد و استفاده از يليمر

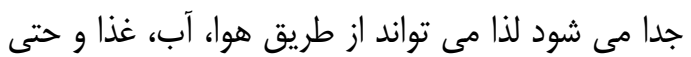

با استفاده از وسايل يزشكى به انسان منتقل شود مهاده).

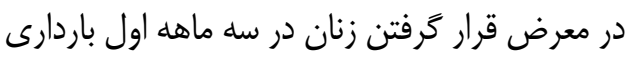
با دى اتيل هخَيل فتالات، باعث كاهش فاصله آنوزنيتال

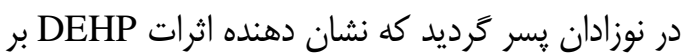

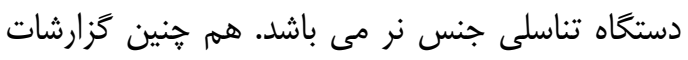

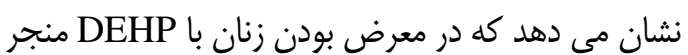
به آنومالى هاى دستخاه تناسلى نوزادان مى گرد درد. نتايج تحقيقات متعدد نشان داده اند كه فتالات ها با دان

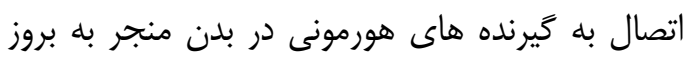
فعاليت هاى آنتى آندروزنى، تغيير در ساختار و كاركرد سلول هاى سرتولى بيضه، كاهش تعداد و كيفيت تحرى

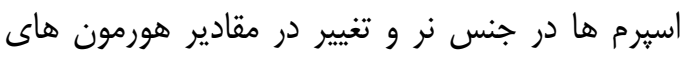

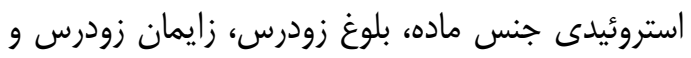

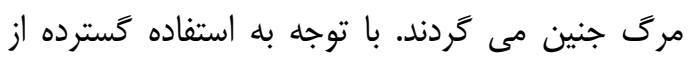

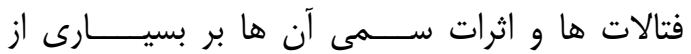

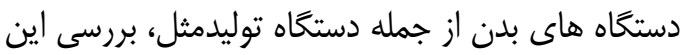

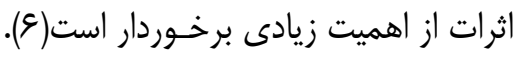

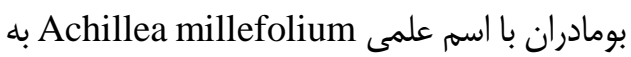

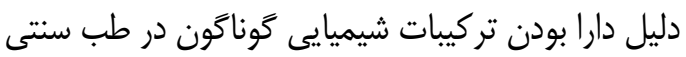
و مدرن استفاده مى شود. Achillea millefolium متعلق به خانواده استراسه آ يك كياه خند سند ساله معطر

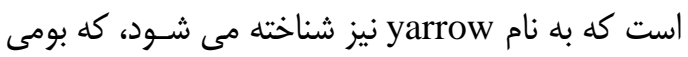

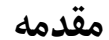

در عصر حاضر نابارورى يكى از مشكلات مهم

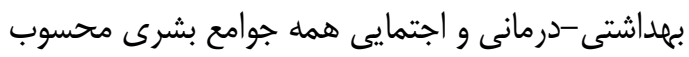

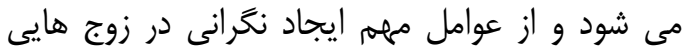

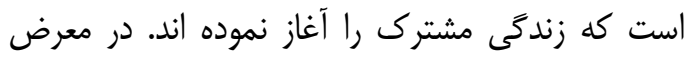
قرار گيرى افراد در برابر عوامل خارجى قبل و بعد از شروع باردارى و نيز طى مراحل اوليه پِ از تولد مى تواند

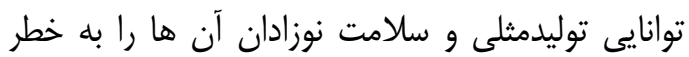

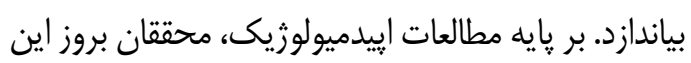
اختلالات توليدمثلى را به يك سرى آلوده كننده هاى بيدائ زيست محيطى كه بر روى دستخاه آندوكرين مهره داران

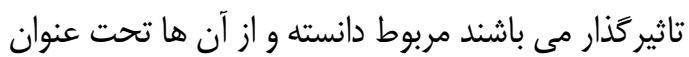

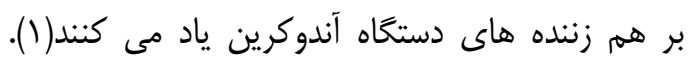

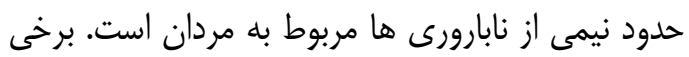
از عوامل موثر بر نابارورى مردان وابسته به عوامل محيطى است. بنا به كَزارش سازمان بهداشت جهانى

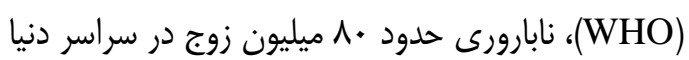
را تحت تاثير قرار داده است، كه •ه درصد آن ها وابسته دارئه به علل مردانه مى باشند(T). فتالات ها يكى از استرهاى محيطى يا مختل كننده

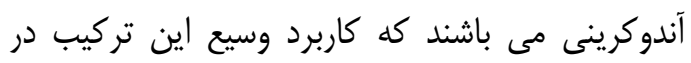

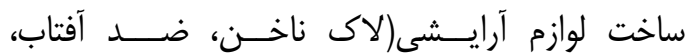

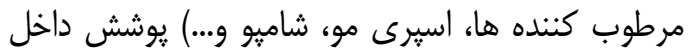

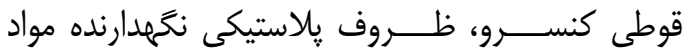
غذايى(مواد لبنى، كَشتى)، ظروف نوشابه، كاغذ ديوارى،

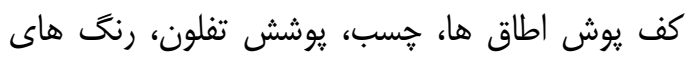

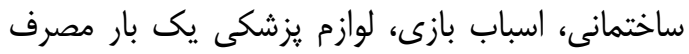

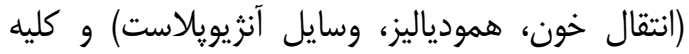

وسايل يلاستيك هاى قابل انعطاف مى بـاشد(َّ).

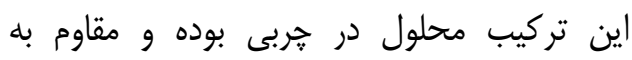
متابوليسم هستند. بر اساس شدت، مدت و تعداد دفعات تماس باعث تغييراتى در عملكرد سيستم آندوكرين به

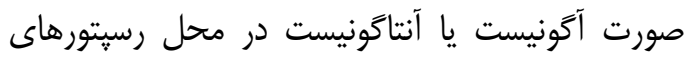

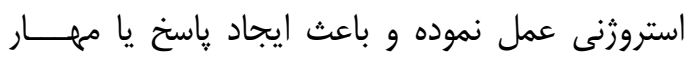

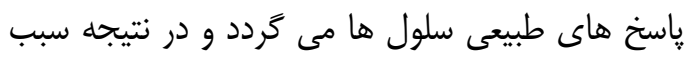

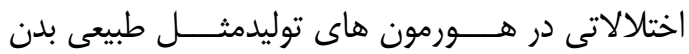

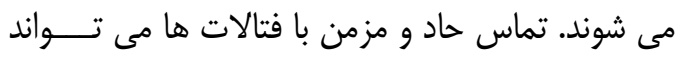




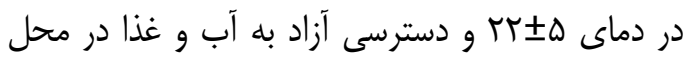

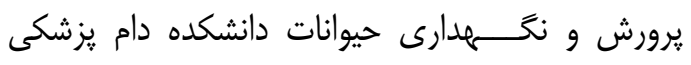

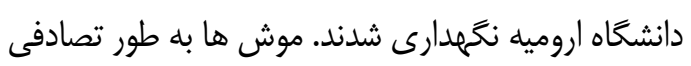

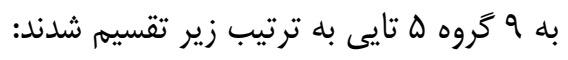

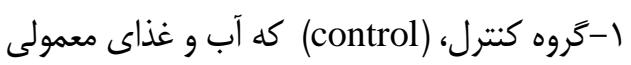
بدون هيج تيمارى دريافت كردند.

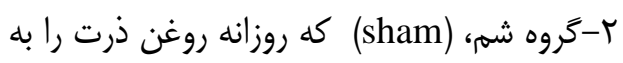

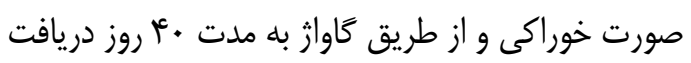
كردند.

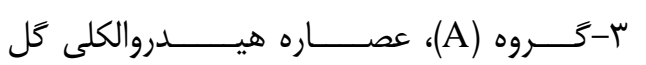

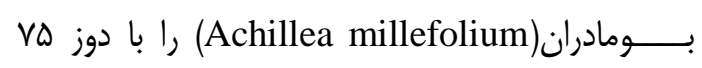

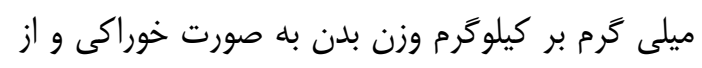

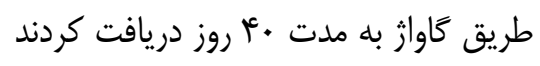

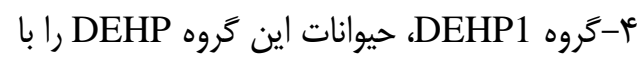

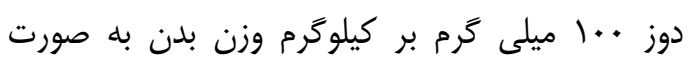

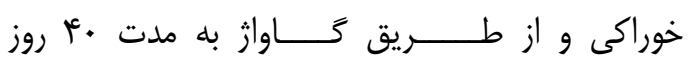

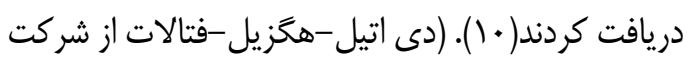
TCI Chemical (9211 North Harbor gate خريدارى Street Portland, OR 97203USA) كرديد). ه- هروه DEHP1+A، حيوانات به طور همزمان

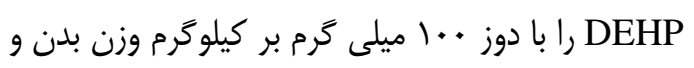

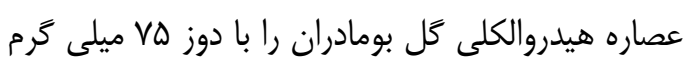

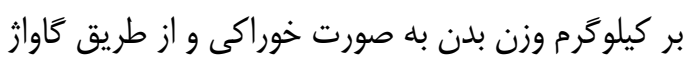
به مدت • ع روز دريافت كردند.

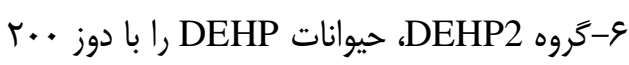

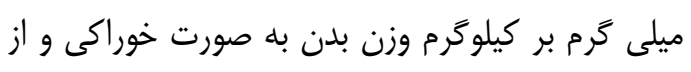

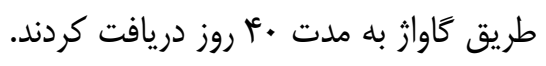

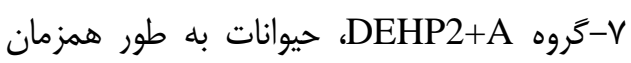
ا ا با دوز . DEHP

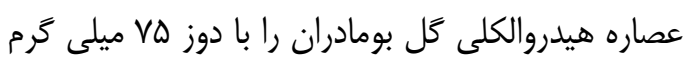

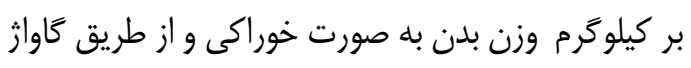
به مدت • ع روز دريافت كردند.

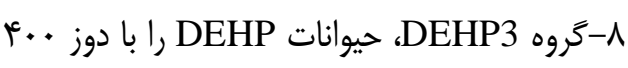

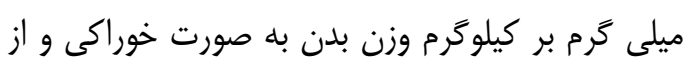

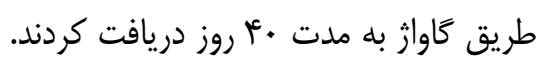

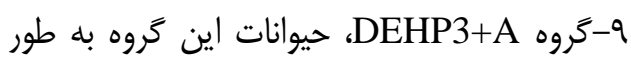
هم زمان DEHP را با دوز +.+ ميلى گرم بر كيلو
ايران مى باشد و در طب سنتى در برابر اختلالات متعدد

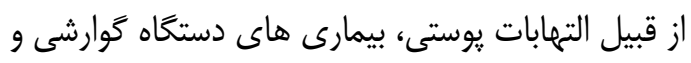
صفراوى كاربرد دارد(V). در يزشكى سنتى ايرانيان، جند گَّنه از بومادران كه به طور كلى در زبان فارسى بومادران ناميده مى شود، به به عنوان ترميم كننده زخهم، ضد التهاب و ضد في اسياسم مورد

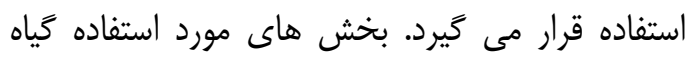

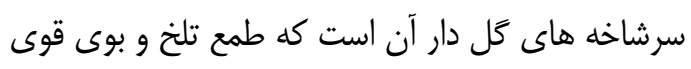
دارد(^). تركيبات شيميايى بومادران حاوى فلاونوئيدها

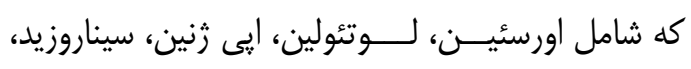

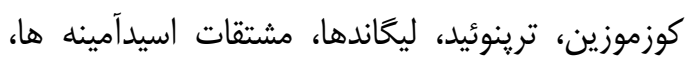
اسيدهاى هرب و آلكاميدها و تركيبات حاوى نيتروزن مى باشند. هم جنين داراى جندين خواص دار دارويى و

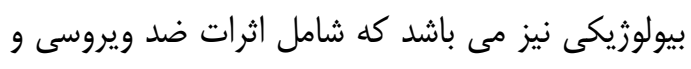
ضدموتاثن و ضد اسياسمى هستند. از جمله موارد استفاده

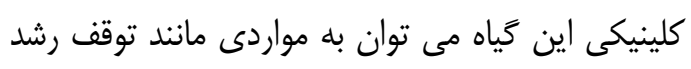
و تخريب سلول هاى سرطانى، ضد درد و ضد التهابى و

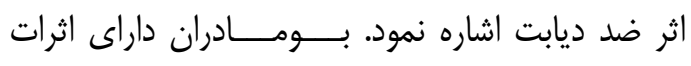

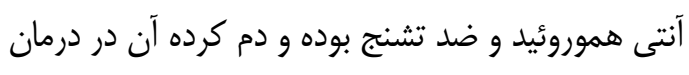

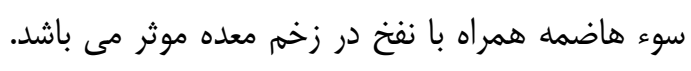

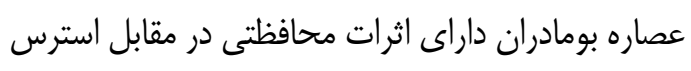

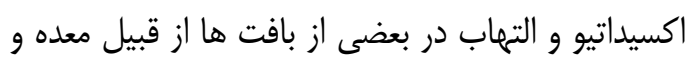

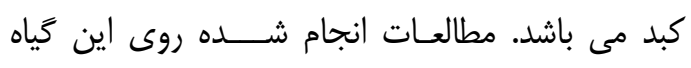

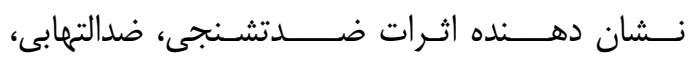

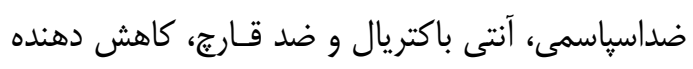
فشارخون و آنتى اكسيدانى است (9).

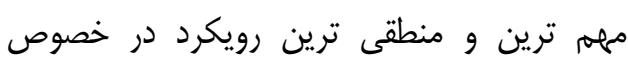

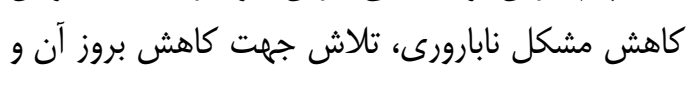

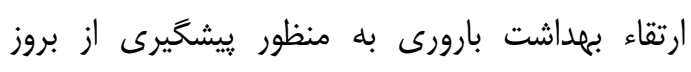

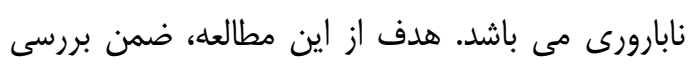

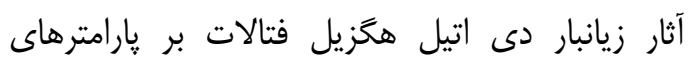

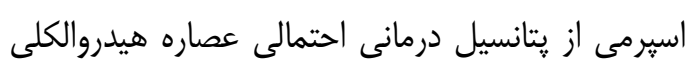

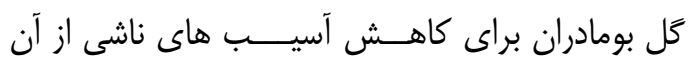
مى باشد.

\section{مواد و روش ها داش}

در اين تحقيق هأ سر موش صحر ايى نر بالغ نزاد

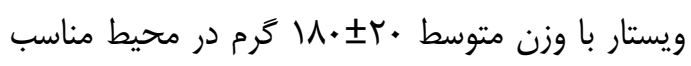

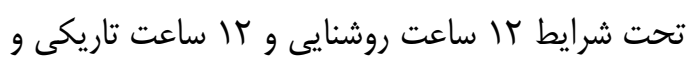


به آن •ا ميكروليتر محيط كشت حاوى اسبرم افزوده

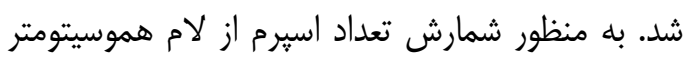

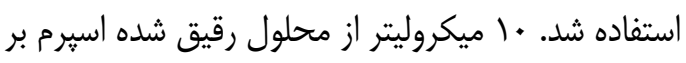

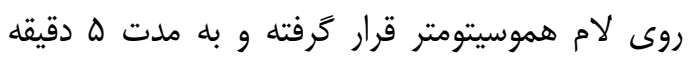

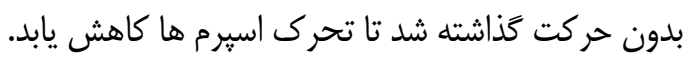

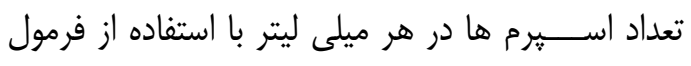

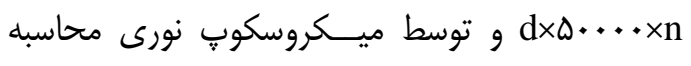
كرديد كه n تعداد اسبرم هاى شمارش شده در در ها ناحيه

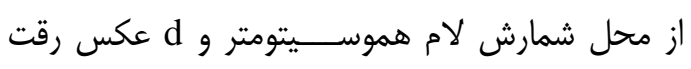
سوسيانسيون حاوى اسيرم مىباشد.

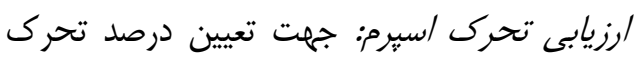

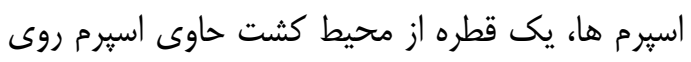

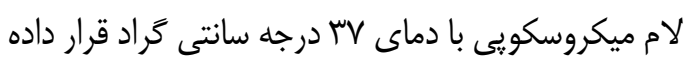

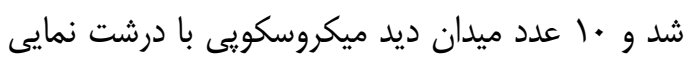

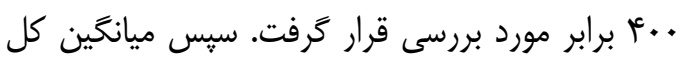

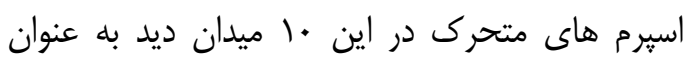
درصد تحرى ثبت كرديد. ارزيابى زنده بودن اسيرم ها: براى ارزيابى درديد

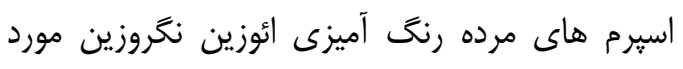

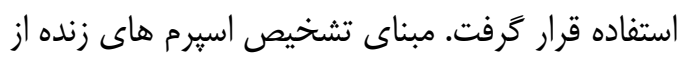

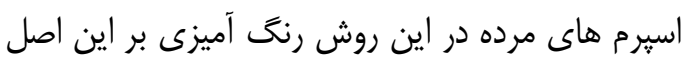

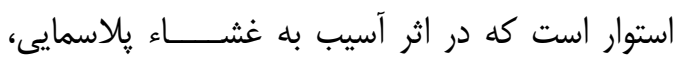

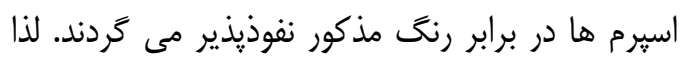

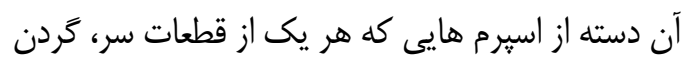

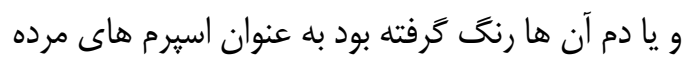

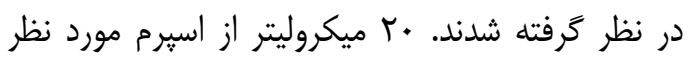

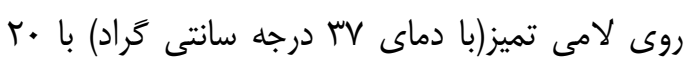

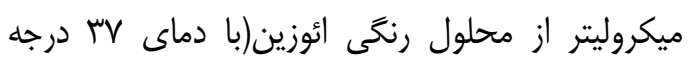

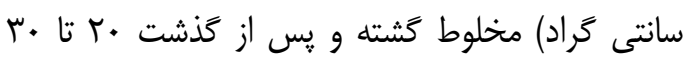

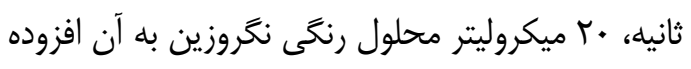

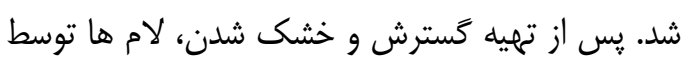
ميكروسكوب نورى جهت تعيين درصد اسبرم هاى زنده

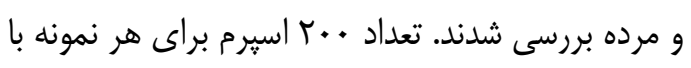

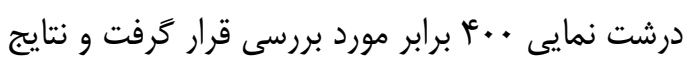
حاصل در قالب درصد بيان شدند.

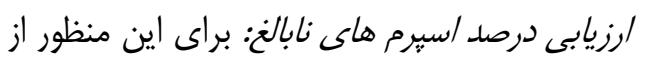

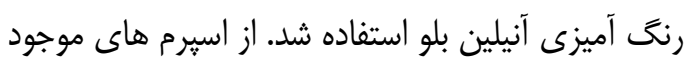

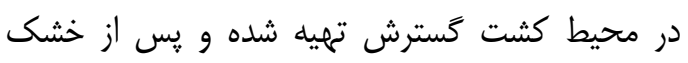

VQ وزن بدن و عصاره هيدروالكلى كل بومادران را با دوز

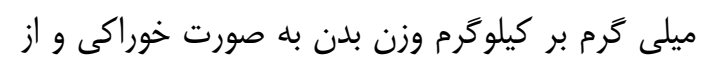
طريق كاواز به مدت • أ روز دريافت كردند.

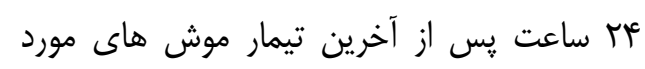

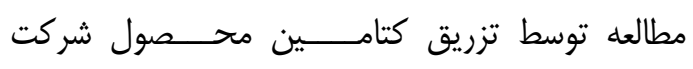
Rotexmedica

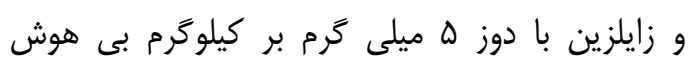

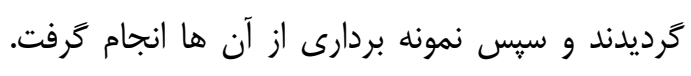

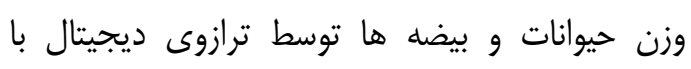

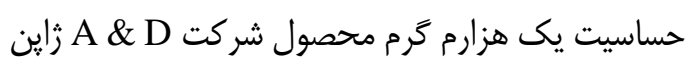
ثبت شدند.

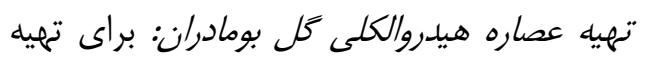

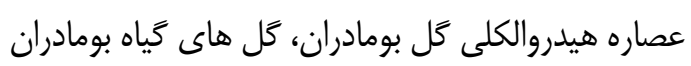
يس از شناسايى توسط گروه گياه شناسى دانشخاه اروميه

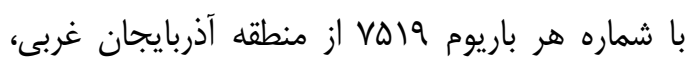

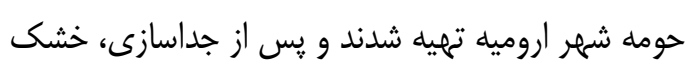

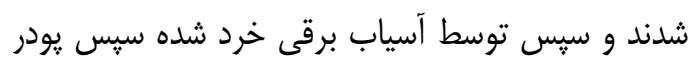

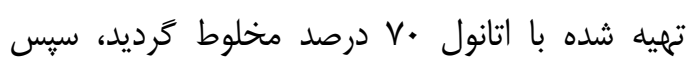

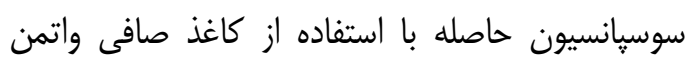
صاف شده و در دستخاه تقطير در خلا(دستخاه روتارى)

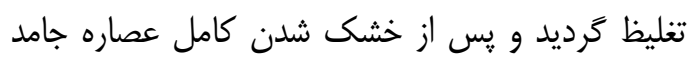

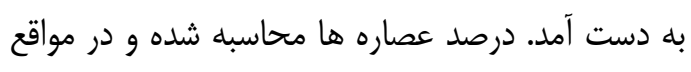
مصرف با آب مقطر رقيق گرديده و مورد استفاده قرار

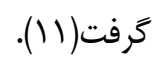
اخذ /سبرم/ز دم/بيديديمرهاى بيضه ها: إيبديديمه ها

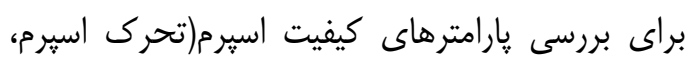

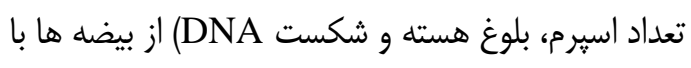

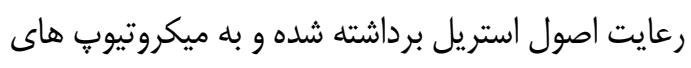

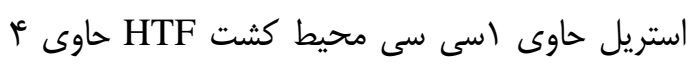

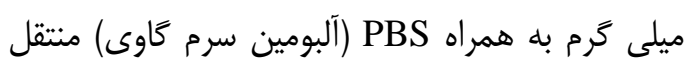
كشتند. اين محيط كشت حاوى دم دم إيديديم ها داخ داخل

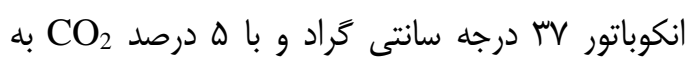
مدت ه ساعت قرار داده شدند تا امكان خروج اسبرم از آن ها فراهم آيد. مله ساعت قرات

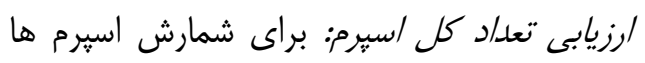

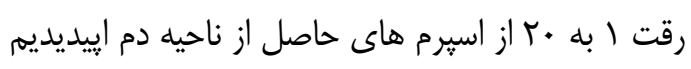

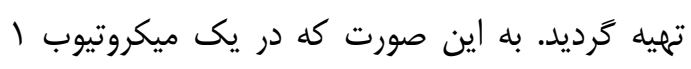
ميلى ليترى، • 19 ميكروليتر آب مقطر ريخته شد و سيس ديس ديك 
اسميرها توسط رنغ اكريدين اورنج تازه تهيه شده(19/ .

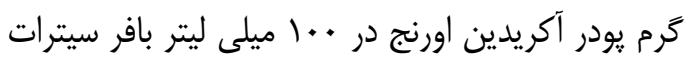

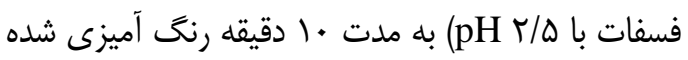
و در زير ميكروسكوب فلورسنت مورد ارزيابى قرار كرفتند. آناليز آمارى: داده هاى نرمال با نرم افزار SPSS و و

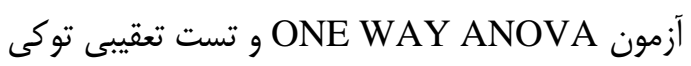
مورد تجزيه و تحليل قرار كرفتند.

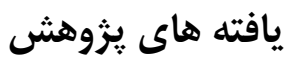

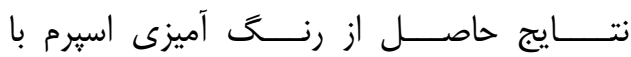

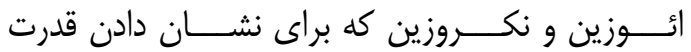

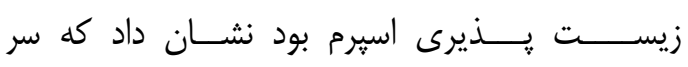

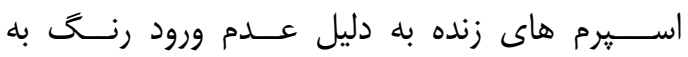

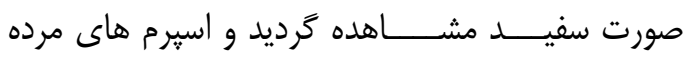

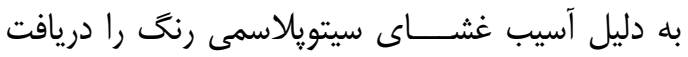

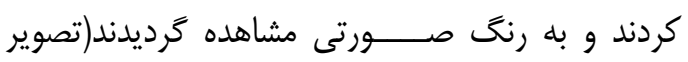

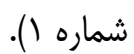

شدن در جريان هوا، نمونه ها توسط فيكساتور

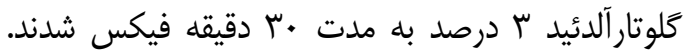
اسميرها توسط محلول رنكى آنيلين بلو ه درصد(به همراه

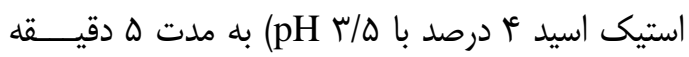

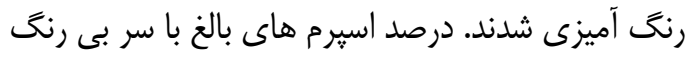

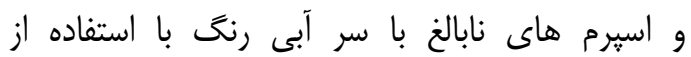
ميكروسكوب نورى به دست آمدند.

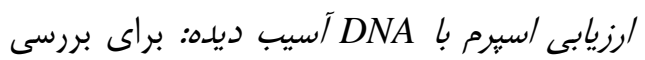

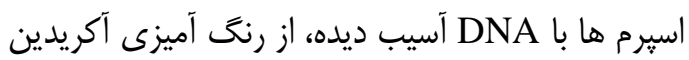
اورنج استفاده شد. اين روش براى جداسازى DNA سالم

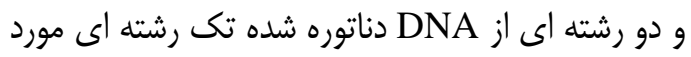

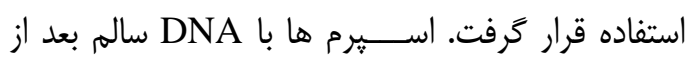

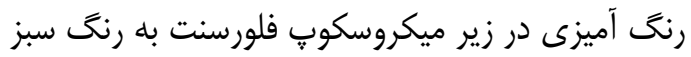

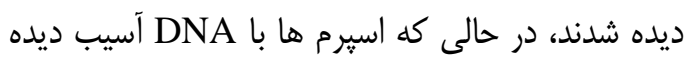
به رنغَ نارنجى تا قرمز مشاهده شدند. اسميرها با با استفاده

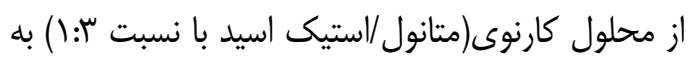

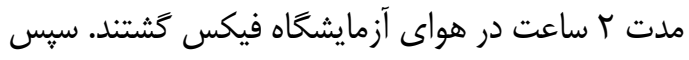

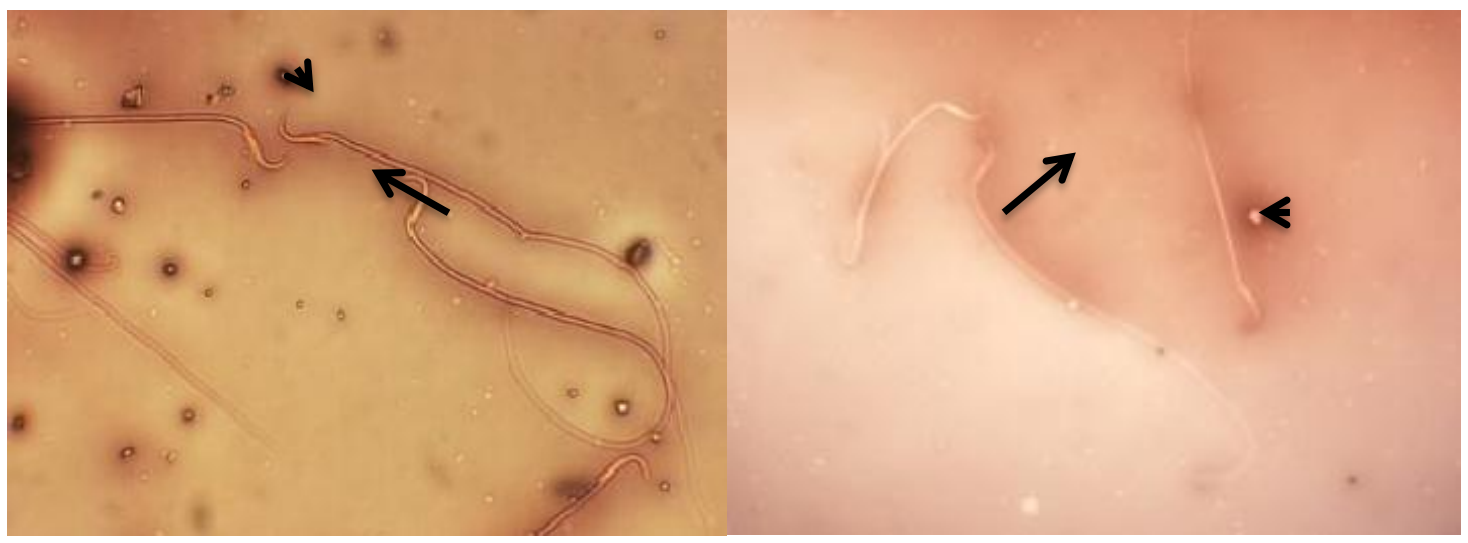

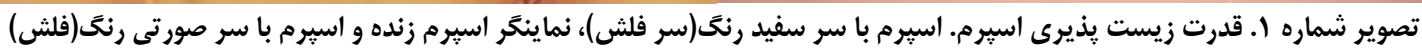

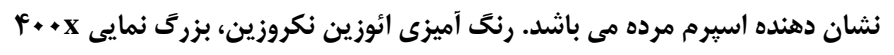

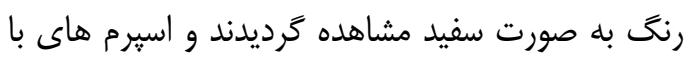

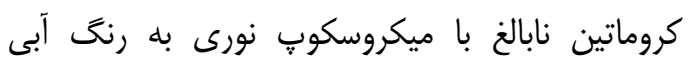
مشاهده گرديدند(تصوير شماره ؟).
نتايج حاصل از رنغ آميزى اسبرم با آنيلين بلو كه

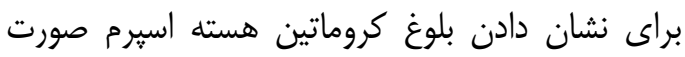

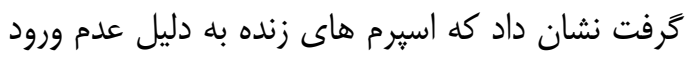




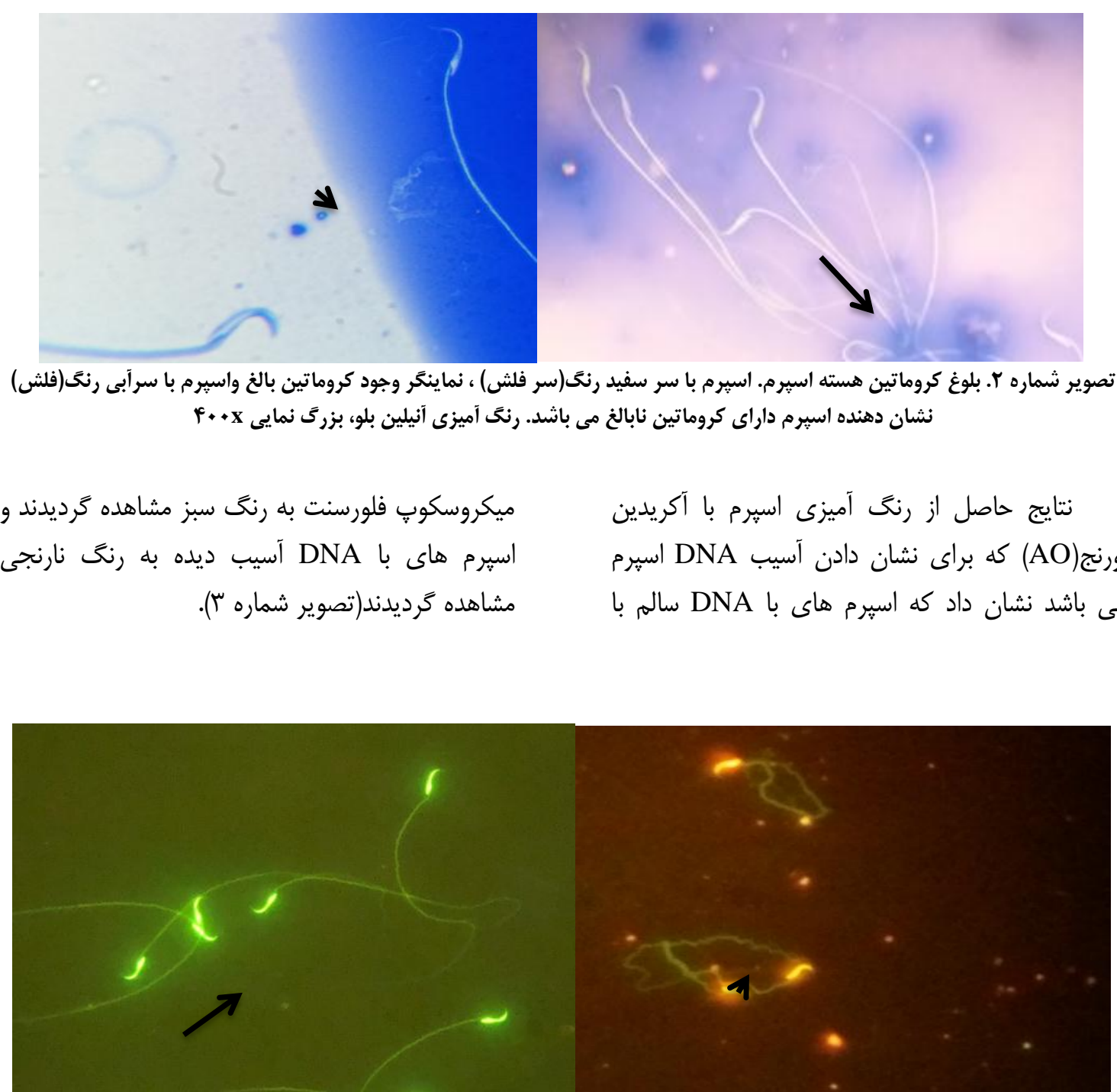

تصوير شماره ऍ. آسيب DNA اسيرم. اسيرم با سر سبز رنغَ(سرفلش)، نشان دهنده اسيرم با DNA سالم, و اسيرم با سر زرد رنحَ(فلش)،

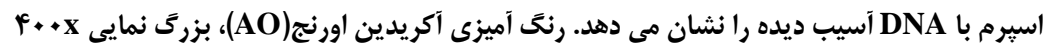

كاهش معنى دارى(P<0.05) در تعداد اسبرم دارند. در

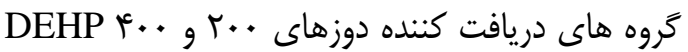

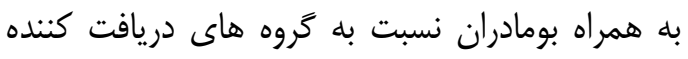

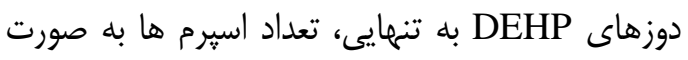
معنى دارى(P<0.05) افزايش يافته بود(نمودار شماره ()).
نتايج مربوط به تعداد /سيرم ها: از نتايج حاصل اين مطالعه مشخص گرديد كه گروه هاى كنترل و شم و

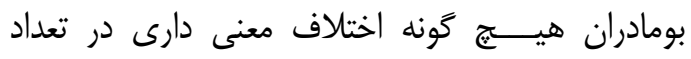

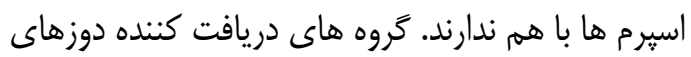

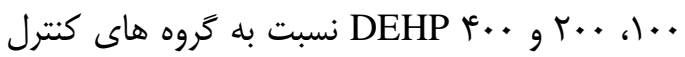




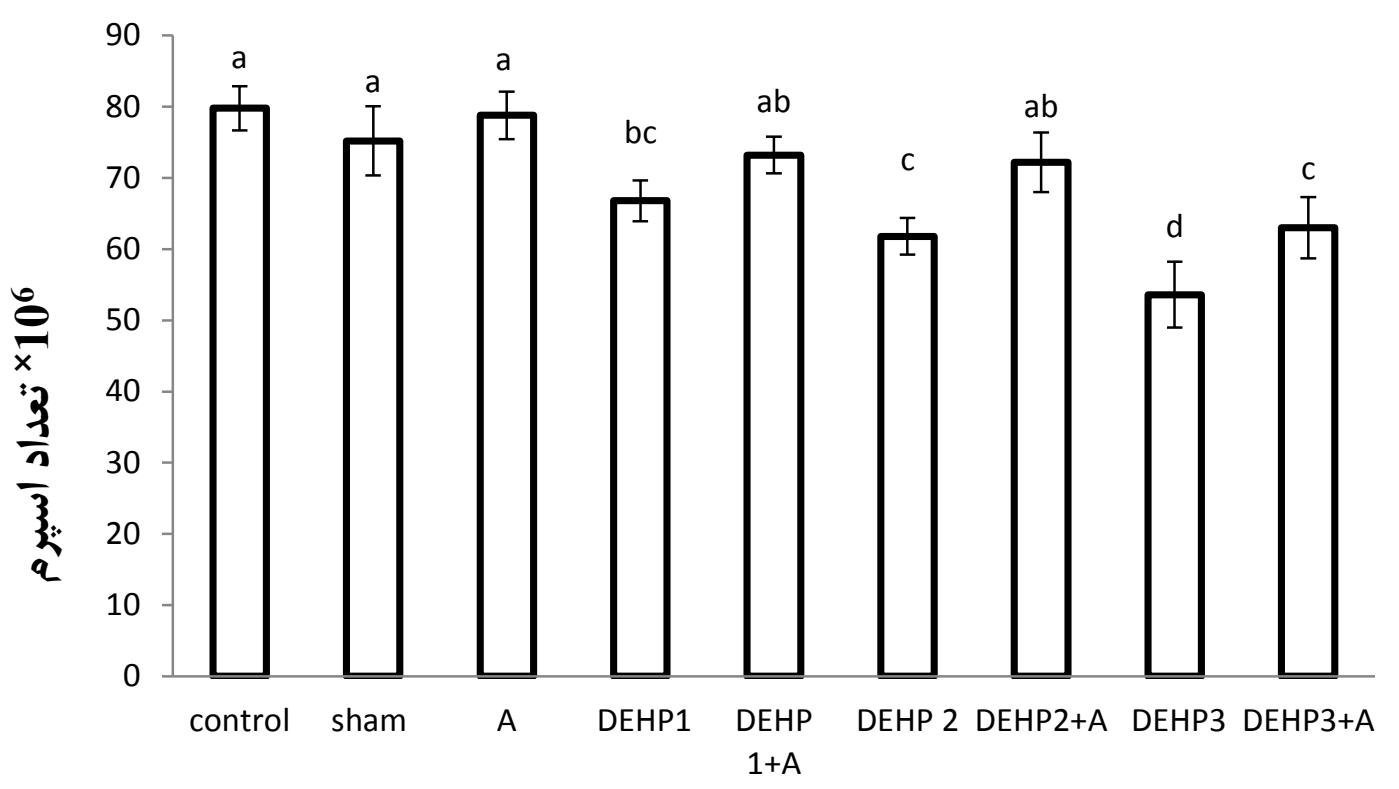

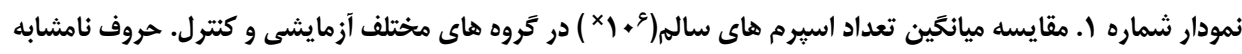

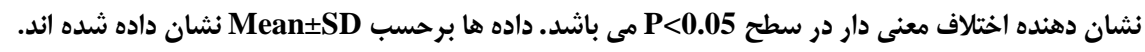

كروه هاى كنترل و شم و بومادران دارند. در گروه هاى

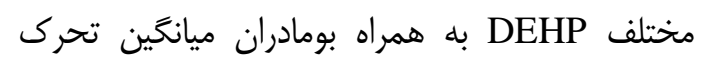

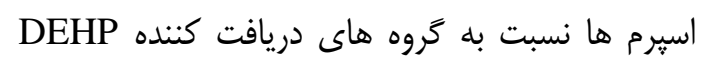

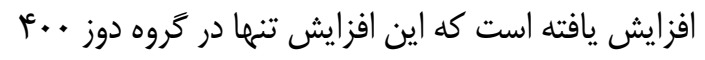

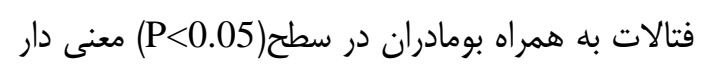

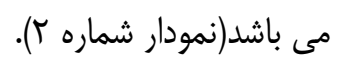

نتايج مربوط به تحرك اسيرم ها: نتايج حاصل

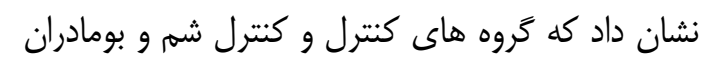

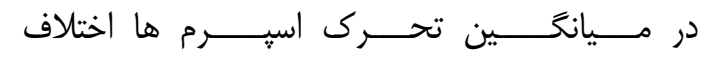

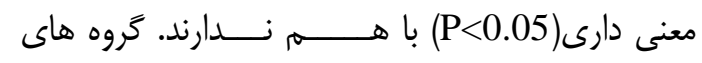

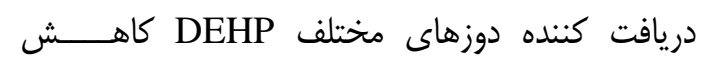

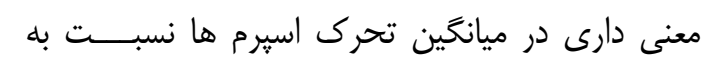

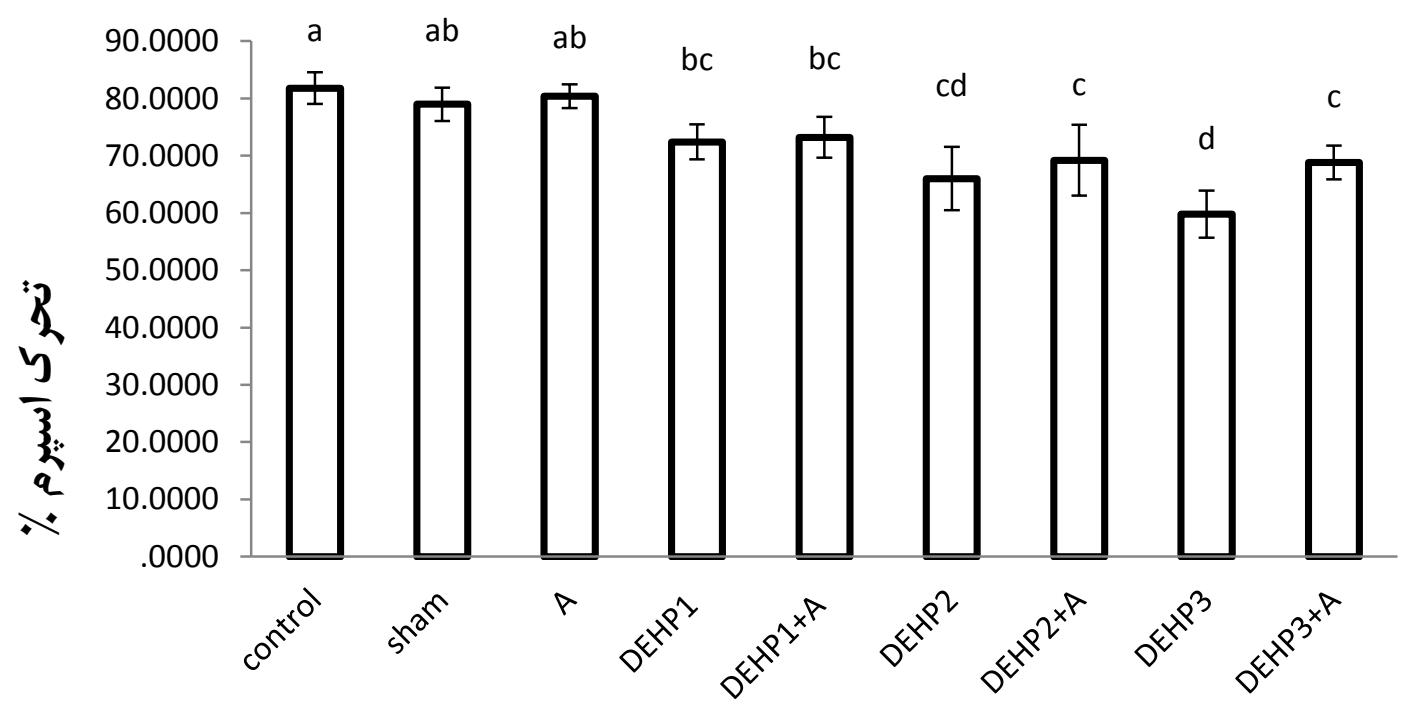

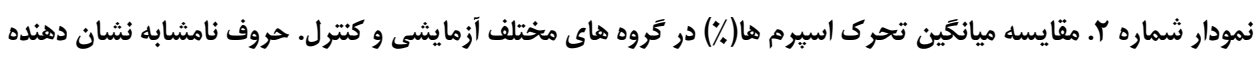

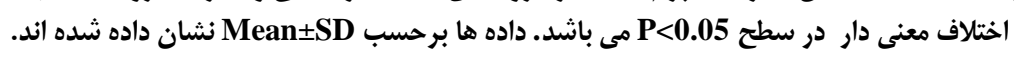


نسبت به كروه هاى كنترل و شم و بومادران داشته است

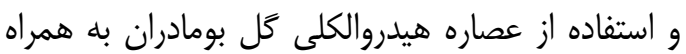

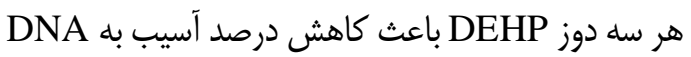

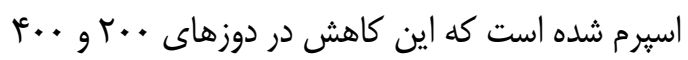

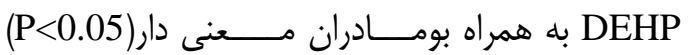
مى باشد. نتايج مربوط به عدم بلوغ هسته نشان داد كه

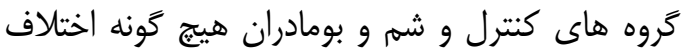

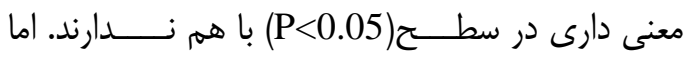
كروه هاى دريافت كننده دوزهاى مختلف فتالات دراس درصد

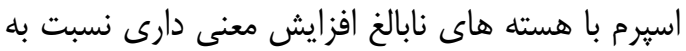
كروه هاى كنترل داشته است كه استفاده از عصاره هيدروالكلى گل بومادران به همراه هر يكى از دوزهاى

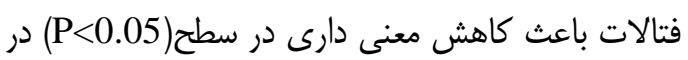
درصد هسته هاى نابالغ اسيرم شده است(جدول شماره
نتايج مربوط به قدرت زيست بذيرى اسيرم ها:

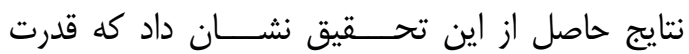

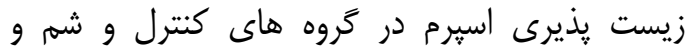

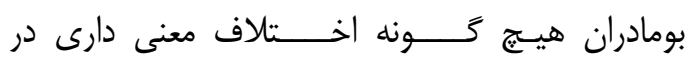

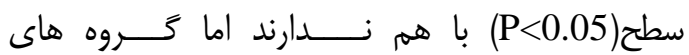
دريافت كننده دوزهاى مختلف فتالات نسبت به گروها همان كنترل، كاهش معنى دارى در سطح(P<0.05) در قدرت

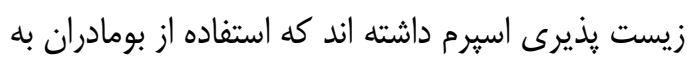

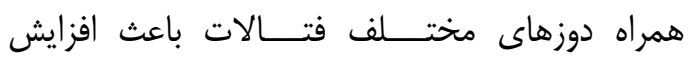
زيست يذيرى اسيرم ها شده است كه اين افــزايش معنى دار(P<0.05) نبوده است(جدول شماره ()).

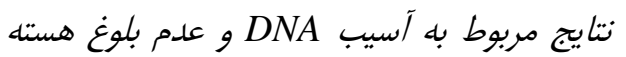
اسيرم ها: نتايج مربوط به آسيب DNA اسيرم نشان داد كه در گروه هاى دريافت كننده دوزهاى مختلف فتالات

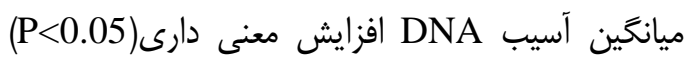

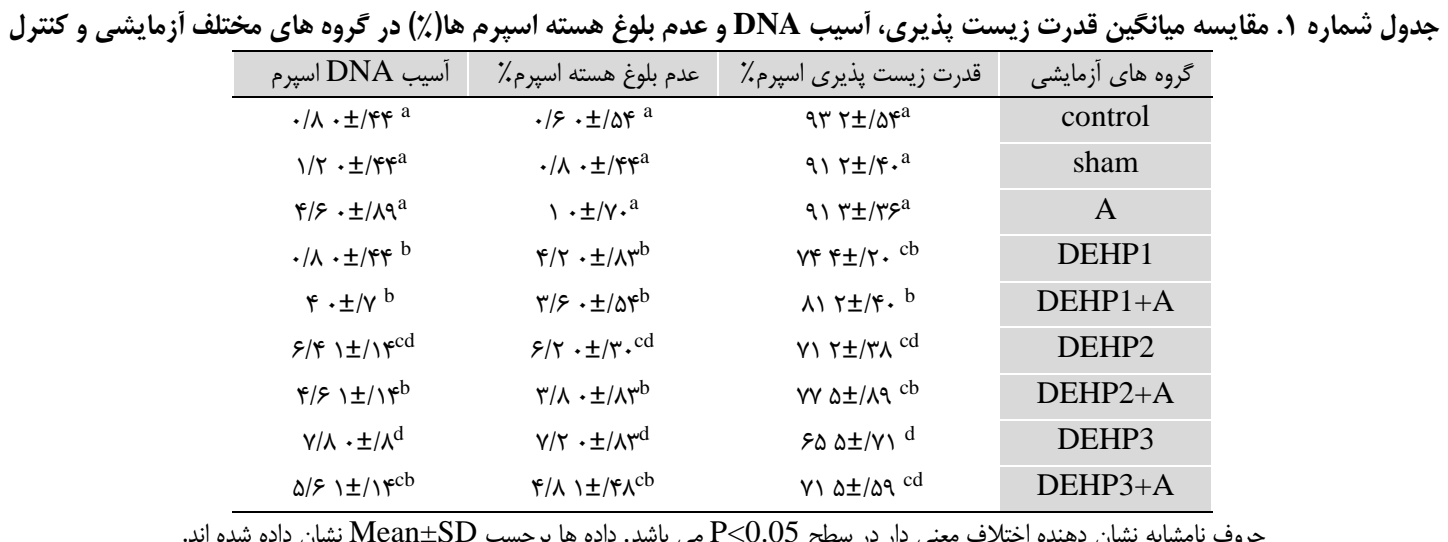

بيضه، كاهش دانسيته اسپرم در إيبديديم و حركت اسِرم شده و هم جنين باعث افزايش اسيرم هاى غيرطبيعى در رت هاى نر مى گرددر(1). بر اساس يافته هاى مطالعه Fang و همكاران، دوز

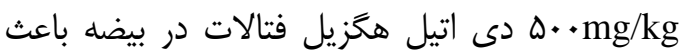
مهار تكثير DNA كه در نهايت آسيب به DNA اسيرم مى شود. افزايش آيويتوز كه در اثر مهار هنغال همانندسازى و در نتيجه منجر به شكستن رشته مى شود، باعث القاى آسيب به ميتوكندرى و افزايش

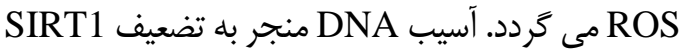
(تنظيم كننده عملكرد ميتو كندرى) و باعث كاهش سطح ATP در بيضه مى شود. كاهش سطوح ATP ممكن
بحث و نتيجه تيرى

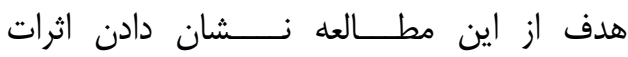
فارماكولوزيكى عصاره هيدروالكلى گل بومادران بر روى إنى بيضه و يارامترهاى كيفيت اسيرم در موش هاى صحر ايى

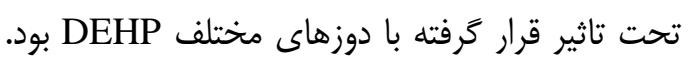
بر اساس نتايج به دست آمده از اين مطالعه مشخص شد كه عصاره هيدروالكلى گل بومادران يارامترهاى كيفيت اسيرم تعداد، تحرك، زنده مانى، بلوغ اسيرم و آسيب

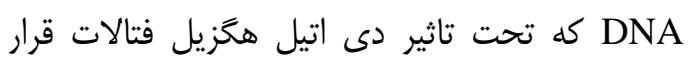
گرفته بودند را بهببود مى بخشد.

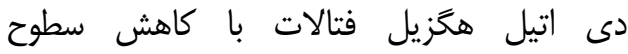
كَادوترويين ها بر بيضه اثر مى كذارد و باعث آتروفى 
كه باعث خنثــى كــــدن راديكال هاى آزاد مى شود

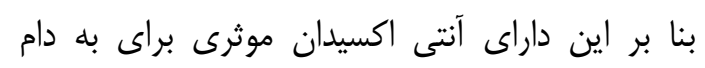

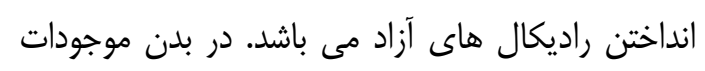

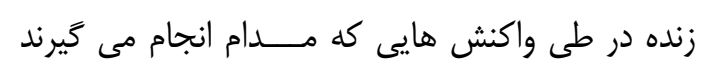

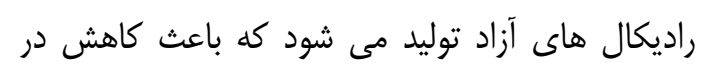

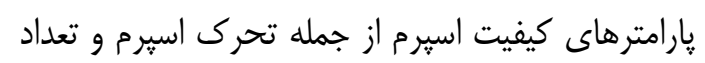

$$
\text { آن ها مى شودا •r). }
$$

كاهش فعاليت آنزيم هاى آنتى اكسيدانى موجب

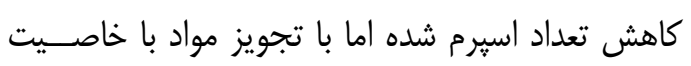

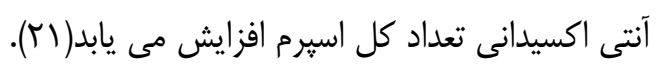
تحقيقات صورت كَرفته نشان داده است كه كَّياه بومادران به سبب دارا بودن ويزگى هاى آنتى اكسيدانتى

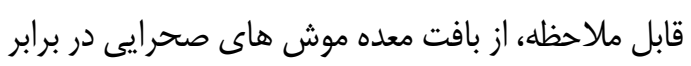
جراحات معدى ناشى از ROS محافظت مى نمايد(T) مارئ.

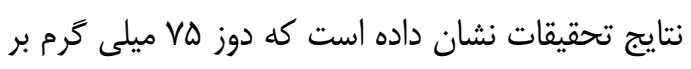

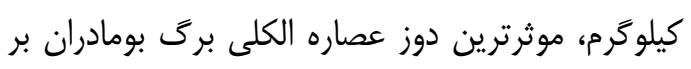

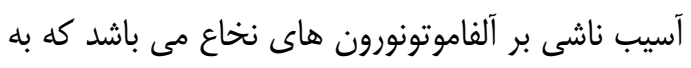
دليل وجود فاكتورهاى رشد و ترميمى كه داراى اثرات

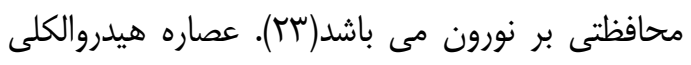

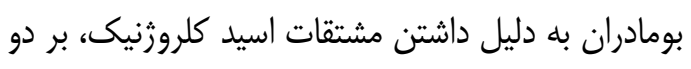

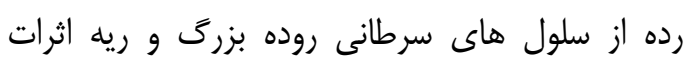

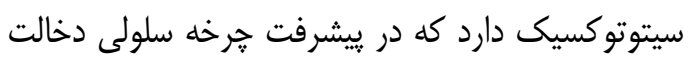

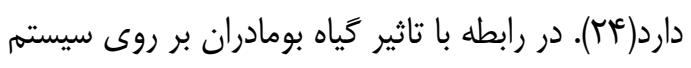
توليدمثلى نتايج ضد و نقيضى گزارش شده است. عصاره

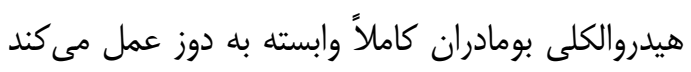

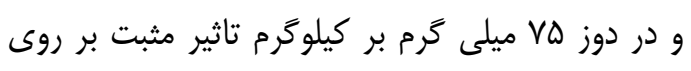

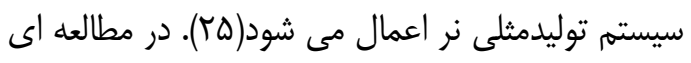

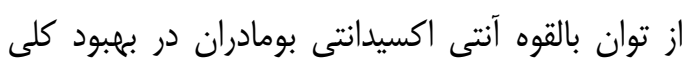

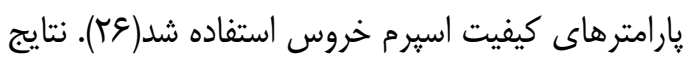

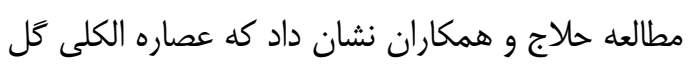

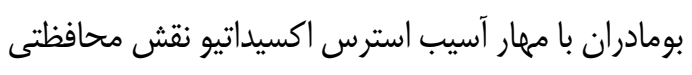
بر نارسايى توليدمثلى در اثر سميت نيكوتين داشته

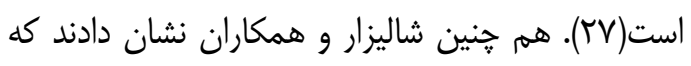

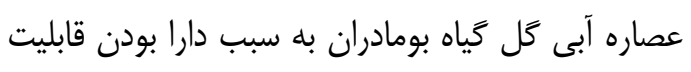
مهار راديكال هاى آزاد و فرآيندهاى اكسيداتيو مى تواند

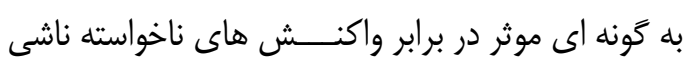

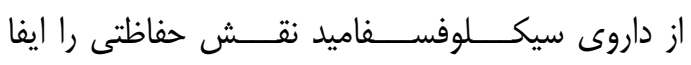

كند)
است منجر به مشكلات در بارورى از قبيل تحرك اسيرم كردد كه به ATP اسيرم وابسته است(سآ (1). در مطالعه

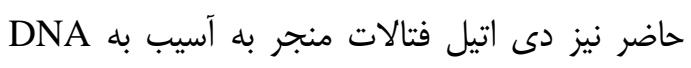
هسته اسيرم كرديده است. استفاده از دوز mg/kg . .0ه دى اتيل هئزيل فتالات در موش سورى، منجر به كاهش توانايى لقاح

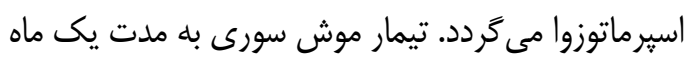

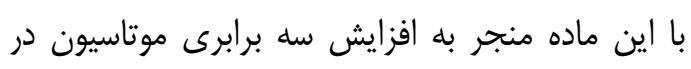
DNA

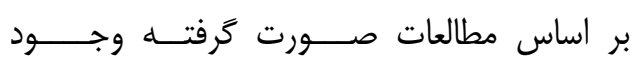
متابوليت هاى فتالات ها در نمونه ادرار مردان، با كاهش ونش

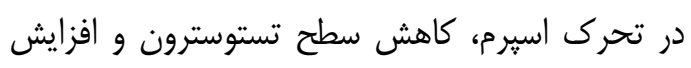

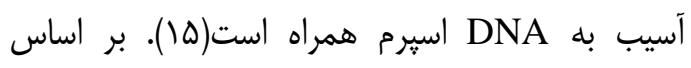
مطالعه pant و همكاران ارتباط بين استرهاى فتالات درم

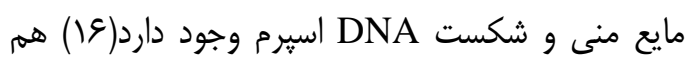

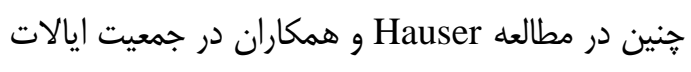

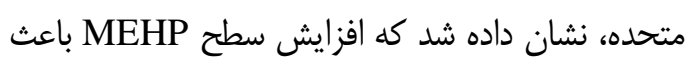

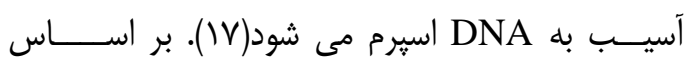

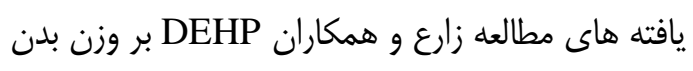

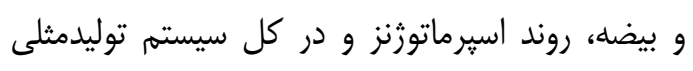

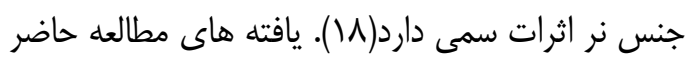

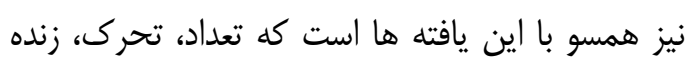

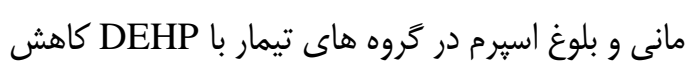

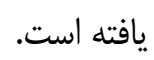

مونو اتيل هخَزيل فتالات(MEHP) مى تواند بيان يروتئين هاى اتصالات سلول هاى سرتولى از جمله و Occludin ، ZO1 N-cadherin ،Catenin) Claudine ) را تغيير بدهد و اين اثر ممكن است به علت (Ca)

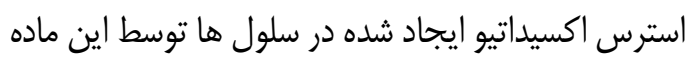

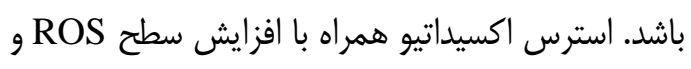

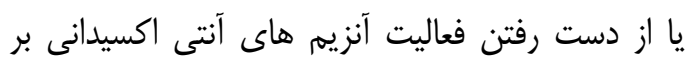
روى عملكرد سلول هاى سرتولى تاثير مى كذاردا افزايش سطح ROS به دليل استرس اكسيداتيو اثرات

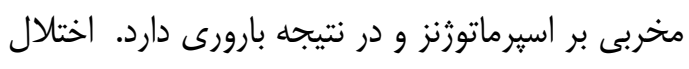
در ساختار و عملكرد سلول هاى سرتولى، كاهش تعداد سلول هاى سرتولى، اسيرماتوسيت ها و اسبرماتيدها به

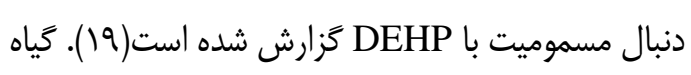

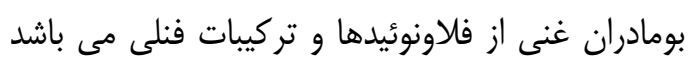




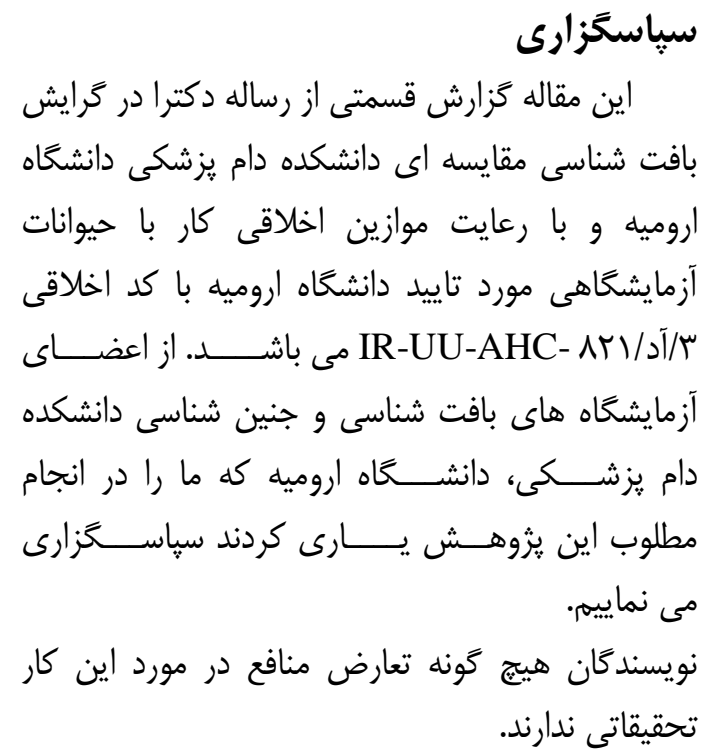

\section{References}

1. Bhasin S, Kretser D, Baker H. Clinical review 64 pathophysiology and natural history of Male infertility. J Clin Endocrinol Metab 1994; 79:1525.

2.Bayasgalan G, Naranbat D, Radnaabazar J, Lhagvasuren T, Rowe P. Male infertility risk factors in Mongolian Men. Asian J Androl 2004; 6:305-11.

3. Carbone S, Szwarcfarb B, Ponzo O, Reynoso R, Cardoso N, Deguiz L, et al. Impact of gestational and lactational phthalate exposure on hypothalamic content of amino acid neurotransmitters and FSH secretion in peripubertal male Rats. Neurotoxicology 2010; 31:747-51. doi.org/10.1016/j.neuro.2010.06.006

4.Quinnies KM, Harris EP, Snyder RW, Sumner SS, Rissman EF. Direct and transgenerational effects of low doses of perinatal di-2-ethylhexyl phthalate on social behaviors in mice. PLos One 2017; 12:41-8. 5.Carbone S, Szwarcfarb B, Ponzo O, Reynoso R, Cardoso N, Deguiz L, et al. Impact of gestational and lactational phthalate exposure on hypothalamic content of amino acid neurotransmitters and FSH secretion in peripubertal male Rats. NeuroToxicology 2010;31: 747-51.

6. Liu T, Li N, Zhu J, Yu G, Guo K, Zhou L, et al. Effects of di-2-ethylhexyl phthalate on the hypothalamus-pituitary-ovarian axis in adult female rats. Reproductive toxicology 2014; 46:141-7. doi.org/10.1016/j. reprotox.2014.03.006

$$
\begin{aligned}
& \text { در نهايت با جمع بندى يافته هــاى مطالعه حاضر } \\
& \text { مى توان خنين نتيجه گيرى كرد كه دى اتيل هخَزيل } \\
& \text { فتالات منجر به آسيب هاى ساختارى و عملكردى دئ در كرد }
\end{aligned}
$$

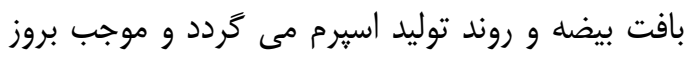

$$
\begin{aligned}
& \text { استرس هاى اكسيداتيو مى گردد و سبب مسموميت } \\
& \text { توليدمثلى دستخاه نر مى شود. از طرف ديخر با تاثير بر الريا } \\
& \text { كيفيت اسيرم ميزان بارورى را كاهش مى دهي دهد. حال آن آن }
\end{aligned}
$$

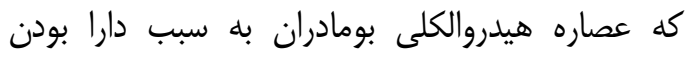

$$
\begin{aligned}
& \text { ويثگى هاى آنتى اكسيدانى قابل ملاحظه و در نتيجه } \\
& \text { مهار استرس اكسيداتيو باعث افزايش اسيرم، كاهش إنى }
\end{aligned}
$$

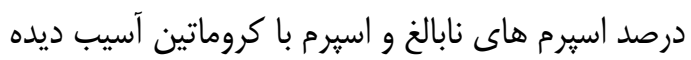

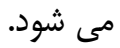

7. Potrich FB, Allemand A, Silva LM, Santos AC, Baggio CH, Freitas CS, et al. Antiulcerogenic activity of hydroalcoholic extract of Achillea millefolium $\mathrm{L}$. involvement of the antioxidant system. J Ethnopharmacol 2010; 130:85-92.

8. Saeidnia S, Gohari A, Mokhber N, Kiuchi F. A review on phytochemistry and medicinal properties of the genus Achillea. Daru 2011; 19:173-86.

9. Cavalcanti AM, Baggio CH, Freitas CS, Rieck L, Sousa RS, Silva JE, et al. Safety and antiulcer efficacy studies of Achillea millefolium L. after chronic treatment in wistar Rats. J Ethnopharmacol2006; 107:277-84. doi.org/10.1016/j. jep.2006.03.011

10. Karabulut G, Barlas N. Genotoxic histologic immunohistochemical morphometric and hormonal effects of di-2ethylhexyl-phthalate on reproductive systems in pre pubertal male Rats. Toxicol Res 2018; 7:859-73. doi. 10.1039/C8TX00045J

11. Rashidi I, Taherimoghadam M, Mozaffari A. [Study of anti-inflammatory and healing effects of Achillea millefolium in the treatment of indomethacin induced gasthic ulcer in Rat]. Qazvin Uni Med Sci J2005; 8:9-13. (Persian)

12. Agarwal DK, Eustis S, Reel JR, Kluwe WM. Effects of di 2-ethylhexyl phthalate on the gonadal pathophysiology, sperm morphology, and reproductive performance 
of male Rats. Environ Health Perspect 1986; 65:343-50. doi.org/10.1289/ehp.8665343

13. Li X, Fang EF, Scheibye M, Cui H, Qiu $\mathrm{L}$, Li J, et al. di-2-ethylhexyl phthalate inhibits DNA replication leading to hyperparylation SIRT1 attenuation and mitochondrial dysfunction in the testis. Sci Rep2014;

4:6434.Doi.org/10.1038/srep06434

14. Huang XF, Li Y, Gu YH, Liu M, Xu Y, Yuan Y, et al. The effects of di-2-ethylhexyl phthalate exposure on fertilization and embryonic development in vitro and testicular genomic mutation invivo. Plos One2012; 7:22-8.

15.Jurewicz J, Radwan M, Sobala W, Ligocka D, Radwan P, Bochenek M, et al. Human urinary phthalate metabolites level and main semen parameters sperm chromatin structure sperm aneuploidy and reproductive hormones. Rep Toxicol 2013; 42:232-41.

doi.org/10.1016/j.reprotox.2013.10.001

16. Pant N, Shukla M, Patel DK, Shukla Y, Mathur N, Gupta YK, et al. Correlation of phthalate exposures with semen quality. Toxicol Appl pharmacol 2008; 231:1126.doi.org/10.1016/j.taap.2008.04.001

17. Hauser R, Meeker J, Singh N, Silva M, Ryan L, Duty S, et al. DNA damage in human sperm is related to urinary levels of phthalate monoester and oxidative metabolites. Hum Rep2007; 22:688-95. doi.org/10.1093/humrep/del428

18. Zare Z, Eimani H, Mohammadi M, Mofid M, Dashtnavard $\mathrm{H}$. [Histopathological study of di-2-ethylhexyl phthalate on testes in Mouse]. J Mazandaran Uni Med Sci 2009; 19:52-9. (Persian)

19. Agarwal A, Saleh RA, Bedaiwy MA. Role of reactive oxygen species in the pathophysiology of human reproduction. Fert Ster2003; 79:829-43. doi.org/10.1016/S0015-0282(02)04948-8

20. Gilguzman E, Ollero M, Lopez M, Sharma R, Alvarez J, Thomas JRA, et al. Differential production of reactive oxygen species by subsets of human spermatozoa at different stages of maturation. Hum Rep 2001; 16:1922-30.

doi.org/10.1093/humrep/16.9.1922
21.Acharya UR, Mishra M, Patro J, Panda MK. Effect of vitamins $\mathrm{C}$ and $\mathrm{E}$ on spermatogenesis in mice exposed to cadmium. RepToxicol 2008; 25:848.doi.org/10.1016/j.reprotox.2007.10.004 22. Zolghadri Y, Fazeli M, Kooshki M, Shomali T, Karimaghaie N, Dehghani M. Achillea Millefolium L. hydro- alcoholic extract protects pancreatic cells by down regulating IL- $1 \beta$ and iNOS gene expression in diabetic Rats. Int J Mole Cell Med2014; 3:255-62.

23. Alikhanzade $\mathrm{M}$, Tehranipour $\mathrm{M}$. [Investigating the neuroprotective effect of alcholic extracts of Achillea biebersteinii leave on $\alpha$ motoneurons after sciatic nerve compression in Rats]. SSUJ 2014; 22:132332. (Persian)

24. Pereira JM, Peixoto V, Teixeira A, Sousa D, Barros L, Ferreira IC, et al. Achillea millefolium L. hydroethanolic extract inhibits growth of human tumor cell lines by interfering with cell cycle and inducing apoptosis. Food Chem Toxicol 2018;118:635-

44.doi.org/10.1016/j.fct.2018.06.006

25. Asliranifam N, Hasanzadeh SH, Najafi $\mathrm{GH}$. [The effects of hydroalcholic extract of Achillea Millefolium on invitro fertilization and emberyonic development process in Mice]. Qom Uni Med Sci J 2017; 10: 23-3. (Persian)

26.Najafi RA, Taheri A, Najafi AA, Rouhollahi M. Effect of Achillea millefolium loaded nanophytosome in the post thawing sperm quality and oxidative status of rooster semen. Cryobiology 2018;2: 4-11.

27. Salahipour $\mathrm{MH}$, Hasanzadeh $\mathrm{S}$, Malekinejad H. Ameliorative effects of Achillea millefolium inflorescences alcoholic extract against nicotine-induced reproductive failure in Rat. Exp Toxicol Pathol2017;

69:504-16. doi.org/10.1016/j.etp.2017.04.012

28.Jalali AS, Hasanzadeh S, Malekinejad H. Achillea millefolium inflorescence aqueous extract ameliorates cyclophosphamideinduced toxicity in rat testis: stereological evidences. Chinese J Natural Med2012, 10: 247-54. doi. 10.1016/S18755364(12)60050-8 


\title{
The Ameliorative Effects of Achillea millefolium Inflorescence Hydro Alcoholic Extract on Sperm Parameters in Male Rats Exposed to Diethyl-Hexyl-Phthalate
}

\author{
Karimpouraliabad $Z^{1}$, Hasanzadeh $S^{* 2}$, Razi $M^{2}$
}

(Received: September 28, 2019

Accepted: January 13, 2020)

\begin{abstract}
Introduction: Esters of phthalates, particularly di-(2-ethylhexyl)-phthalate (DEHP) generally utilized in plastic industry are environmental hazardous pollutants, has toxic effects on body systems, including reproductive system. The aim of this study was to evaluate the effects of Achillea millefolium on rats' sperm exposed to DEHP.
\end{abstract}

Materials \& Methods: In this study, 45 male rats were randomly divided into 9 groups. 1Control, 2- sham, received corn oil, 3received $75 \mathrm{mg} / \mathrm{kg} /$ day hydro alcoholic extract of Achillea millefolium inflorescence, 4- Low-dose diethyl-hexylphthalate (DEHP1), 5- Low-dose diethylhexyl-phthalate+Achillea millefolium, (DEHP1+A) 6- Medium-dose diethylhexyl-phthalate (DEHP2), 7- Medium-dose diethyl-hexyl-phthalate + Achillea millefolium, (DEHP2+A) 8- High-dose diethyl-hexyl-phthalate (DEHP3), 9- Highdose diethyl-hexyl-phthalate + Achillea millefolium (DEHP3+A). All of groups except the control group were treated by gavage for 40 days. After euthanized, the epididymal sperms are collected to investigate the sperm parameters. Data were analyzed using ANOVA and Tukey post hoc tests.

Findings: $\quad$ di-(2-ethylhexyl)-phthalate significantly $(\mathrm{P}<0.05)$ decreased the sperm parameters including, count, viability, motility and maturation of the nucleus and significantly increased the breakage of sperm nuclear DNA in comparison to control group. Achillea millefolium inflorescence hydro alcoholic extract had a positive effect on these parameters.

Discussion \& Conclusions: More likely Achillea millefolium inflorescence hydro alcoholic extract has antioxidant effects thus reduces the injurious effects of di-ethylhexyl phthalate on sperm parameters.

Keywords: di-(2-ethylhexyl)-phthalate, Achillea millefolium inflorescence, Rat, Sperm

1. Dept of Comparative Histology, Faculty of Veterinary Medicine, Urmia University, Urmia, Iran

2. Dept of Veterinary Basic Sciences, Faculty of Veterinary Medicine, Urmia University, Urmia, Iran

*Corresponding author Email: s.hasanzadeh@urmia.ac.ir

Scientific Journal of Ilam University of Medical Sciences 